bility is much more likely to have been the principal controlling factor, as I discuss at some length in a recent article (Hallam, 1972).

As regards Reid's suggestion that a simple lowering of temperature away from the tropics was in itself unlikely to have been the most significant environmental control for the Mesozoic faunas, as has been widely assumed, I can only agree wholeheartedly. I am strongly in accord with his view that increased seasonal effects towards the poles, as in illumination and plankton productivity, are likely to have been far more potent in the comparatively equable Mesozoic climate. Attention ought perhaps to be drawn here to the somewhat similar views expressed by Valentine (1971), who argues for the importance of trophic resource stability as the prime factor controlling latitudinal faunal distributions even at the present day. Certainly it seems that the old simplistic notions of temperature control, which have hitherto dominated discussion of the topic of Mesozoic faunal provinces, must be abandoned in the light of modern ecological knowledge.

\title{
References
}

Hallam, A. 1972. Diversity and density characteristics of Pliensbachian-Toarcian molluscan and brachiopod faunas of the North Atlantic margins. Lethaia 5, 389412.

Valentine, J. W. 1971. Plate tectonics and shallow marine diversity and endemism, an actualistic model. System. Zool. 20, 253-64.

Department of Geology and Mineralogy

A. HALLAM

University of Oxford

9th October 1972

\section{On some highest Llandovery red beds and graptolite assem- blages in Britain and Eire}

SIR,-Graptolite assemblages strongly indicative of the crenulata Zone have recently been collected by the writer and others from two localities associated with highest Llandovery marine red beds. These are at Doon Rock, Kilbride Peninsular, Co. Mayo, Eire, and Hebblethwaite Hall Gill (SD 69109313), Howgill Fells, Northern England. On Swindale Beck in the Cross Fell inlier, Burgess, Rickards \& Strachan (1970) established for the first time the age of the Llandovery red mudstones as belonging to the crenulata Zone, although elsewhere it had been shown that this formation is underlain by a greistoniensis assemblage and overlain by a centrifugus Zone assemblage (Rickards, 1967, 1970).

The Hebblethwaite Hall Gill locality has been recently exposed following the removal by gales of a large tree rooted on the red beds outcrop. Three $\mathrm{cm}$ of dark gree graptolitic mudstone (sensu Rickards, 1964) are exposed in the core of the anticliny depicted by Rickards (1967, pl. 12) and are positioned approximately in the middle of the $12 \mathrm{~m}$ of red beds exposed on this section. The following fauna was obtained with some difficulty: Monoclimacis sp., Monograptus ?marri (Perner), M. priodon (Bronn) common, $M$. sp. nov. (Hutt species), $M$. spiralis (Geinitz), $M$. tullbergi Bouček, $M$. ex gr. nodifer Törnquist sensu stricto, Petalograptus sp. and retiolitid fragments (specimen nos. Sedgwick Museum A81980-81999). The red beds on this section are underlain by graptolitic mudstones yielding a greistoniensis assemblage and are overlain by slightly coarser mudstones with a rich centrifugus Zone (Wenlock) fauna. Some elements of this undoubted high Llandovery red beds fauna are not very diagnostic zonally, but the abundance of $M$. priodon in this position, and the general nature of the assemblage strongly suggests a crenulata Zone age, and indicates that the red beds are of the same 
age as the Llandovery red beds of Cross Fell. The lithologies of the red mudstones and associated rocks, and the sequence of rock types, is identical in both areas.

Figure 1 illustrates the stratigraphy of a part of the Doon Rock area of the Kilbride Peninsula. Some $18.5 \mathrm{~m}$ of red mudstones (Tonalee Formation) are poorly exposed south of the fell road and these are overlain by approximately $33 \mathrm{~m}$ of mostly fine-grained, greenish mudstones (Benbeg mudstone unit of Piper, 1972, p. 44) but including dark graptolitic mudstone between 28.6 and $30.0 \mathrm{~m}$ above the base. This thick unit (locality 2) has yielded the brachiopods Orbiculoidea sp. and Pentlandella pentlandica (Haswell) in addition to numerous well-preserved graptolites referable to the following species: Retiolites geinitzianus geinitzianus (Barrande), Monoclimacis cf. linnarssoni (Tullberg), $M$. vomerina cf. vomerina (Nicholson), Monograptus priodon (Bronn), $M$. aff. nodifer Törnquist, $M$. 'Spirograptus' sp. and 'Diversograptus' inexpectatus (Bouček \& Pribyl) (Specimen nos. Sedgwick Museum A74942-75011). The last three species, particularly, suggest a Llandovery age whilst ' $D$ '. inexpectatus is a crenulata Zone species in Czechoslovakia. The other species are in accord with this assignation, the absence of cyrtograptids in such a rich assemblage indicating Llandovery rather than Wenlock rocks, and the presence of abundant $M$. priodon indicating very high Llandovery.

Elsewhere the Tonalee Formation has been dated as C6, or crenulata Zone (e.g. Cocks et al. 1971, fig 8) and the Benbeg mudstone unit at the base of the Lettergesh Formation should also be placed here.

Stratigraphically above locality 2 are $3 \mathrm{~m}$ of fine-grained, greenish mudstone similar to the beds below the graptolitic horizon. Approximately $6.5 \mathrm{~m}$ of dolerite sill then intervenes between the Benbeg mudstone and the coarser, sandy greywacke of the succeeding

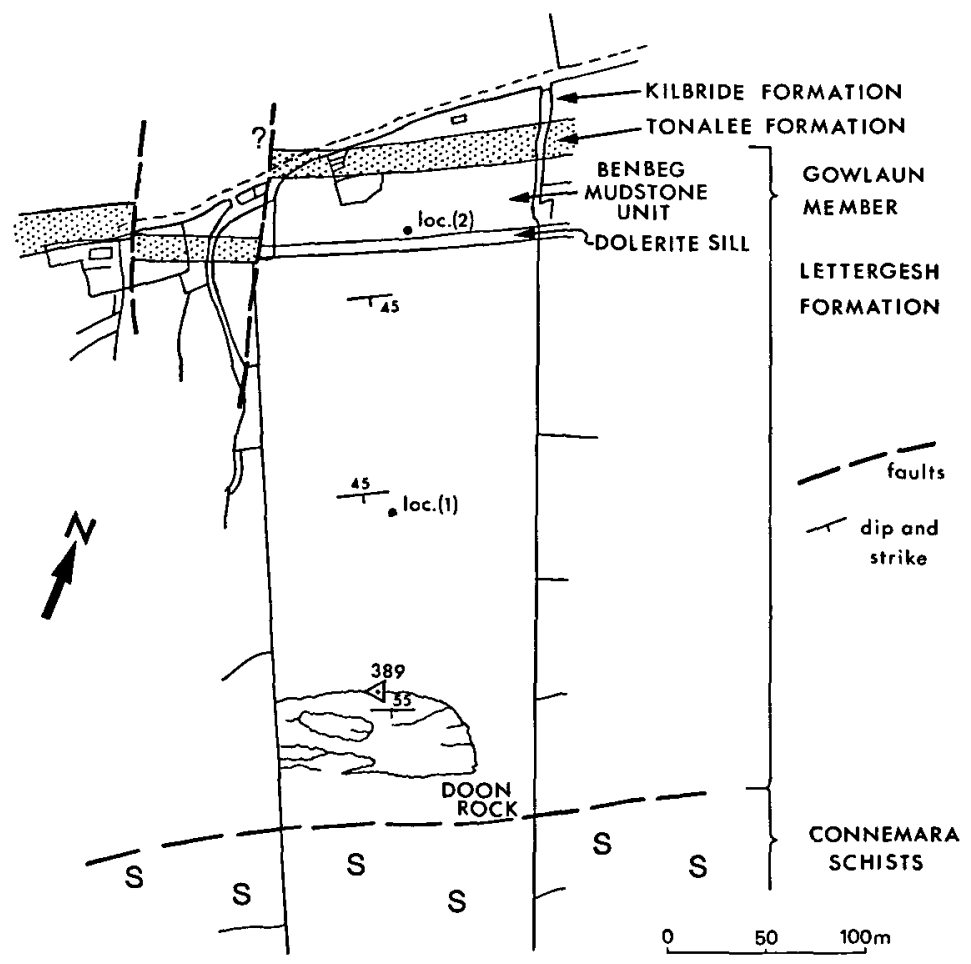

Figure 1. Geology in the region of Doon Rock, Co. Mayo, showing the graptolite localities mentioned in the text. 
Gowlaun Member of the Lettergesh Formation (in terms of older usage: the Upper Owenduff Group). $115 \mathrm{~m}$ stratigraphically above the top of locality 2 are a few $\mathrm{cm}$ of graptolitic mudstone between coarser greywackes (locality 1, Fig 1) which yielded rare specimens of Retiolites geinitzianus geinitzianus (Barrande). The upper limit of this species in Britain is, so far as the writer is aware, about the top of the centrifugus Zone (Wenlock). Thus the lowest part of the Lettergesh Formation, above the Benbeg mudstone unit, is not older than upper crenulata Zone or younger than basal Wenlock. This broadly agrees with the observations of Rickards \& Smyth (1968) who recorded a murchisoni Zone fauna from low in the Lettergesh Formation near Clonbur, although at that locality the base of the formation was not seen.

Thus the marine red beds of the Howgill Fells, Cross Fells, and Kilbride Peninsula are not only of similar thickness and lithology but are at least approximately the same age.

I am indebted to Dr D. Palmer, Dr B. Lock and others for assistance in collecting the Irish locality, and Miss H. Barton and Miss V. Moreton for similar help with the Howgill Fells locality.

\section{References}

Burgess, I. C., Rickards, R. B. \& Strachan, I. 1970. The Silurian strata of the Cross Fell area. Bull. geol. Surv. G.B. 32, 167-82.

Cocks, L. R. M., Holland, C. H., Rickards, R. B. \& Strachan, I. 1971. A correlation of Silurian rocks in the British Isles. $J /$ geol. Soc. Lond. 127, 103-36.

Piper, D. J. W. 1972. Sedimentary environments and palaeogeography of the late Llandovery and earliest Wenlock of North Connemara, Ireland. Jl geol. Soc. Lond. 128, 33-51.

Rickards, R. B. 1964. The Graptolitic Mudstones and Associated Facies in the Silurian Strata of the Howgill Fells. Geol. Mag. 101, 435-51.

1967. The Wenlock and Ludlow succession in the Howgill Fells (north-west Yorkshire and Westmorland). Q. Jl geol. Soc. Lond. 123, 215-51.

1970. The Llandovery (Silurian) Graptolites of the Howgill Fells, Northern England. Palaeontr. Soc. (Monogr.) 123, 1-108.

Rickards, R. B. \& Smyth, W. R. 1968. The Silurian graptolites of Mayo and Galway. Sci. Proc. R. Dubl. Soc. Ser. A, 3, 129-35.

Sedgwick Museum

R. B. RICKARDS

Cambridge CB2 3EQ

20th October 1972

\section{From the Natural Environment Research Council}

SIR, Geochemical Maps-The first of a series of geochemical maps at a scale of $\frac{1}{1}$ in. to 1 mile, based essentially on stream-sediment analyses, was placed on open file at Geochemical Division, 64-78 Gray's Inn Road, London WC1X 8NG, on the 11 September 1972. Copies are also available for consultation at the IGS offices in Edinburgh and Leeds. The map covers Sheet 6, Caithness (Central and Eastern) and part of Sheet 5, Sutherland and parts of Caithness, Ross and Cromarty, of the Geological Survey of Great Britain (Scotland) quarter inch geological map series. The area is also represented by Sheets 102, 103, 109, 110, 116 and the eastern part of Sheet 115 of the 1 in. to 1 mile geological maps of Scotland.

The geochemical data are unsmoothed and presented as proportional symbols at each sampling point, the minimum mean sample density being one sample per $2 \mathrm{~km}^{2}$. The distribution of the following elements is shown: 